\title{
Expression and Localization of Endothelin-1 and Endothelin Receptors in Human Meningiomas

\author{
Evidence for a Role in Tumoral Growth
}

Uberto Pagotto, “ Thomas Arzberger, ${ }^{\ddagger}$ Ursula Hopfner, * Joachim Sauer, * Ulrich Renner, “ Christopher J. Newton, * Manfred Lange, ${ }^{\S}$ Eberhard Uhl," Adolf Weindl, ${ }^{\star}$ and Günter K. Stalla*

*Max-Planck Institute of Psychiatry, Clinical Institute, 80804 Munich, Germany; ${ }^{\ddagger}$ Departments of Neurology, Technical University of Munich, 81675 Munich, Germany; ${ }^{\S}$ Departments of Neurosurgery, Hospital of Mannheim, University of Heidelberg, 68167 Mannheim, Germany; and "Departments of Neurosurgery of University of Munich, 81377 Munich, Germany

\begin{abstract}
In addition to its well-known homoeostatic actions in the cardiovascular system, ET-1 has been shown to constitute a potent growth regulatory peptide in various tissues. We have studied the expression of ET-1 and its receptors (ETAr and ET-Br $)$ in human meningiomas $(n=35)$ as well as their involvement in cellular growth. By PCR of reversetranscribed RNA we detected ET-1 mRNA in 91\% (32 of 35), ET-Ar mRNA in $82 \%$ ( 29 of 35$)$, and ET-Br mRNA in $42 \%$ ( 15 of 35 ) of human meningiomas examined. The localization of ET-1 mRNA, ET-Ar mRNA, and ET-1 peptide in tumoral cells was observed by in situ hybridization and immunohistochemistry, whereas ET-Br mRNA was expressed at low level only in cells belonging to blood vessels. In addition, we found that ET-1 stimulated $\left[{ }^{3} \mathrm{H}\right]$ thymidine incorporation in primary cell cultures of 20 meningiomas and that this effect could be blocked by BQ-123, a specific antagonist for ET-Ar. In contrast, RES-701-3, an antagonist of ET-Br, did not block the proliferative effect of ET-1. In conclusion, our data provide evidence that ET-1 constitutes an important growth factor for meningiomas acting via ETAr. We can hypothesize that ET-1, acting in concert with other growth factors and cytokines, is involved in the meningioma tumorigenesis. (J. Clin. Invest. 1995. 96:2017-2025.) Key words: brain tumors - endothelin-A receptor $\cdot$ endothelin-B receptor • endothelin antagonists $\bullet$ in situ hybridization
\end{abstract}

\section{Introduction}

Originally isolated by Yanagisawa in 1988 from culture media of vascular endothelial cells $(1)$, endothelin $(E T)^{1}$ is comprised

Part of this work was presented at the 39th Symposium of German Society of Endocrinology and was published in abstract form (1995. Exp. Clin. Endocrinol. Diab. 103[Suppl. 1]:169).

Address correspondence to Uberto Pagotto, M.D., Max-Planck Institute of Psychiatry, Clinical Institute, Kraepelinstrasse, 2-16, $80804 \mathrm{Mu}-$ nich, Germany. Phone: 49-89-30622-270; FAX: 49-89-30622-200.

Received for publication 18 April 1995 and accepted in revised form 7 July 1995.

1. Abbreviations used in this paper: DIG, digoxigenin; EMA, epithelia membrane antigen; ET, endothelin; ET-Ar, ET-A receptor; ET-Br, ETB receptor; IHC, immunohistochemistry; ISH, in situ hybridization; $\mathrm{rt}$ room temperature; RT, reverse transcriptase; S6c, Sarafotoxin 6c.

J. Clin. Invest.

(C) The American Society for Clinical Investigation, Inc.

0021-9738/95/10/2017/09\$2.00

Volume 96, October 1995, 2017-2025 of three different peptides: ET-1, ET-2, and ET-3 (2). Two human ET receptors have been cloned and pharmacologically characterized: the isopeptide-selective ET-A receptor (ET-Ar) which preferentially binds ET-1 (3) and which is specifically antagonized by BQ-123 (4), and the ET-B receptor (ET-Br) which is known to bind ET-1, ET-2, and ET-3 with the same affinity (5).

In addition to their well known homoeostatic and compensatory actions in the cardiovascular system (for review see reference 6), ETs were identified in various areas of human (7) and rat brain $(8)$, mainly in glial cells $(9,10)$, acting as modulators of brain functions (for review see reference 11). Moreover, ET-1 has been described to exert a role in the promotion of mitogenesis in normal and tumoral tissues (for review see reference 12). ET-1 has been shown to stimulate protooncogene expression and growth of fibroblasts (13), endothelial cells (14), and vascular smooth muscle cells (15). Furthermore, the expression and release of ET-1 in human cancer cell lines (16, 17 ) and in human tumors (18-20) suggest a potential role for ET-1 in tumoral growth promotion or maintenance.

An abnormal expression of growth factors or their receptors has been associated with the development of human and animal tumors (21). There is clear evidence that an intratumoral production of growth factors, operating in an autocrine/paracrine manner, may be involved in neoplastic transformation. A growing number of reports have already documented the presence of EGF (22, 23), IGF I and II (24), bFGF (25), TGF $\alpha$ (26), PDGF (27), and their receptors in different types of primary intracranial tumors such as differentiated and undifferentiated gliomas and meningiomas. Receptors for ETs have been found in human gliomas (28), and our group has shown recently that ET-1 immunoreactivity is absent in normal human anterior pituitary but is expressed in $50 \%$ of human pituitary adenomas examined (29).

McCumber (8) described moderate levels of ET-1 expression and ET-1 binding sites in meninges of 19-d rat fetus. Since growth factors have been described to play a role in fetal and neonatal development as well as in neoplastic progression (30), we have investigated whether ET-1 and its receptors are expressed in human meningiomas and normal human meninges. We have also examined whether ET-1 plays a role in the growth of human meningiomas in culture.

\section{Methods}

Tissues. Tumor specimens were obtained from 35 patients ( 13 males and 22 females, age 27-77 yr) operated on for intracranial meningiomas. According to the World Health Organization histological criteria (31), tumors were classified as 14 meningotheliomatous, 9 fibroblastic, 4 transitional, 1 psammomatous, 1 angiomatous, and 6 anaplastic meningi- 


\begin{tabular}{|c|c|c|}
\hline & Sequence $\left(5^{\prime}-\ldots-3^{\prime}\right)$ & cDNA sizes $(b p)$ \\
\hline \multicolumn{3}{|l|}{ Primers } \\
\hline \multicolumn{3}{|l|}{ ET-1 } \\
\hline $5^{\prime}$ & GTCAACACTCCCGAGCACGTT & 304 \\
\hline $3^{\prime}$ & CTGGTTTGTCTTAGGTGTTCCTC & \\
\hline \multicolumn{3}{|c|}{ - } \\
\hline $5^{\prime}$ & CCTTTTGATCACAATGACTTT & 299 \\
\hline $3^{\prime}$ & TTTGATGTGGCATTGAGCATACAG & \\
\hline \multicolumn{3}{|c|}{ 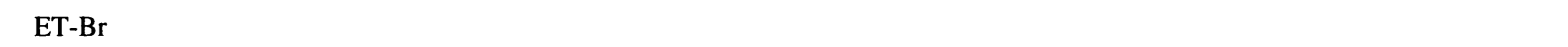 } \\
\hline $5^{\prime}$ & ACTGGCCATTTGGAGCTGAGAT & 428 \\
\hline \multirow[t]{2}{*}{$3^{\prime}$} & CTGCATGCCACTTTTCTTTCTCAA & \\
\hline & Sequence $\left(5^{\prime}---3^{\prime}\right)$ & Positions \\
\hline \multicolumn{3}{|c|}{ Oligonucleotides } \\
\hline \multicolumn{3}{|c|}{ ET-1 } \\
\hline oligo 1 & GCTGTTTCTGGAGCTCCTTGGCAAGCCACAAACAGCAGAGAG & $24-65$ \\
\hline oligo 2 & ATGTGCTCGGTTGTGGGTCACATAACGCTCTCTGGAGGGCTTGCC & $589-633$ \\
\hline \multicolumn{3}{|l|}{ ET-Ar } \\
\hline oligo 1 & AGTGGGTTGATGAGTGGTAACCAGGAAGCTGAGCTCTGTGCCACG & $121-165$ \\
\hline oligo 2 & GTTCATGCTGTCCTTATGGCTGCTCCGGTCTGTGTTGTGGTT & $1240-1281$ \\
\hline \multicolumn{3}{|c|}{$\log$} \\
\hline oligo 1 & GAGATGGTGCGTGGCGGAGATCCTGCCGTCCTGTCTCCTTTA & $216-257$ \\
\hline oligo 2 & GGCACCAGCTTACACATCTCAGTCCCAAATGGCCAGTCCTCTGCC & $489-533$ \\
\hline
\end{tabular}

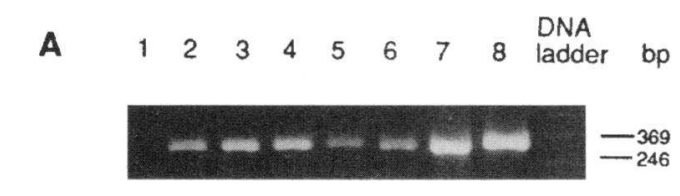

B

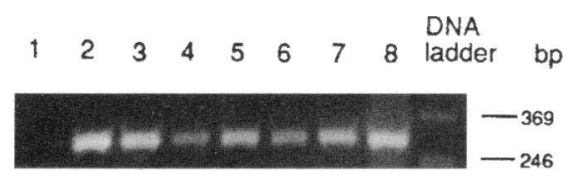

C

omas. Tissue fragments were immediately snap frozen and stored at $-80^{\circ} \mathrm{C}$ for RNA extraction and in situ hybridization (ISH), or immersed in $4 \%$ phosphate-buffered paraformaldehyde for immunohistochemistry (IHC). Additionally, 20 of 35 meningiomas ( 7 meningotheliomatous, 6 fibroblastic, 2 transitional, 1 psammomatous, 1 angiomatous, and 3 anaplastic) were cultured in vitro. Normal human meninges were obtained during autopsies of five patients, who died accidentally, without clinical evidence of neurological diseases.

$R N A$ extraction and reverse transcriptase $(R T)-P C R$. Total cellular RNA was isolated by guanidinium isothiocyanate-phenol-chloroform

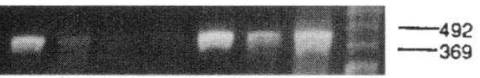

Figure 1. ET-1, ET-Ar, and ET-Br mRNAs detected by RT-PCR in human meningiomas. PCR-cDNA gels show PCR products of $304 \mathrm{bp}$ for ET-1 $(A)$, of 299 bp for ET-Ar $(B)$, and of 428 bp for ET-Br $(C)$ visualized by ethidium bromide. 123 bp DNA ladders were run in parallel as molecular size markers. Lane 1 , negative control obtained in the absence of specific primers; lane 2, meningotheliomatous meningioma; lane 3, fibroblastic meningioma; lane 4, transitional meningioma; lane 5 , psammomatous meningioma; lane 6 , angiomatous meningioma; lane 7 , anaplastic meningioma; and lane 8 , human lung for positive control.

A

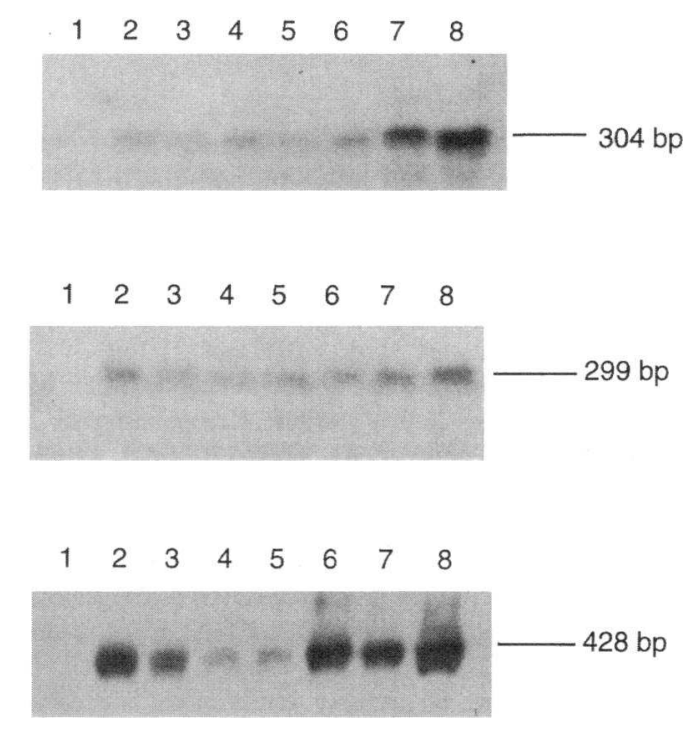

B

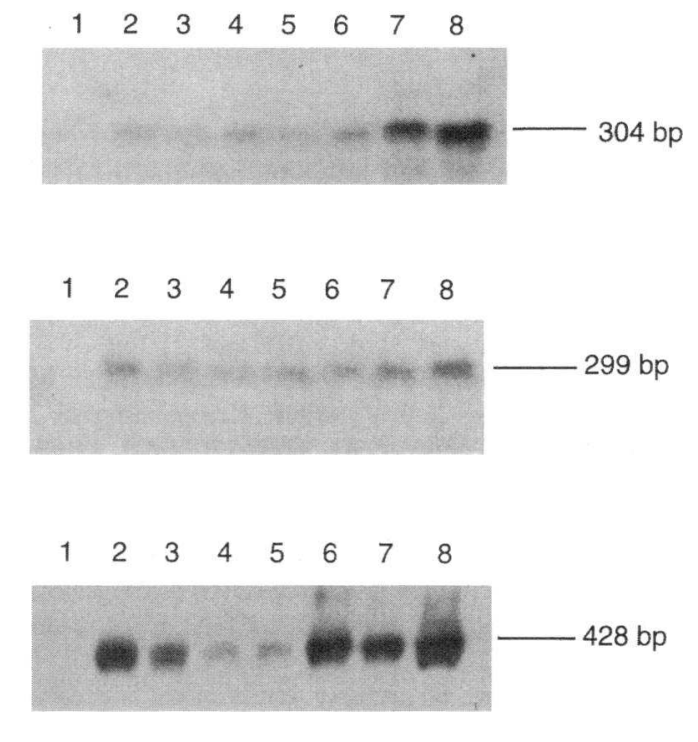

A

Figure 2. Southern blot of the same agarose gel as in Fig. 1 after cheminoluminescent detection demonstrates the absence of nonspecific products. ( $A$ ) ET-1, 304 bp; (B) ET-Ar, 299 bp; and $(C) \mathrm{ET}-\mathrm{Br}$, 428 bp. 

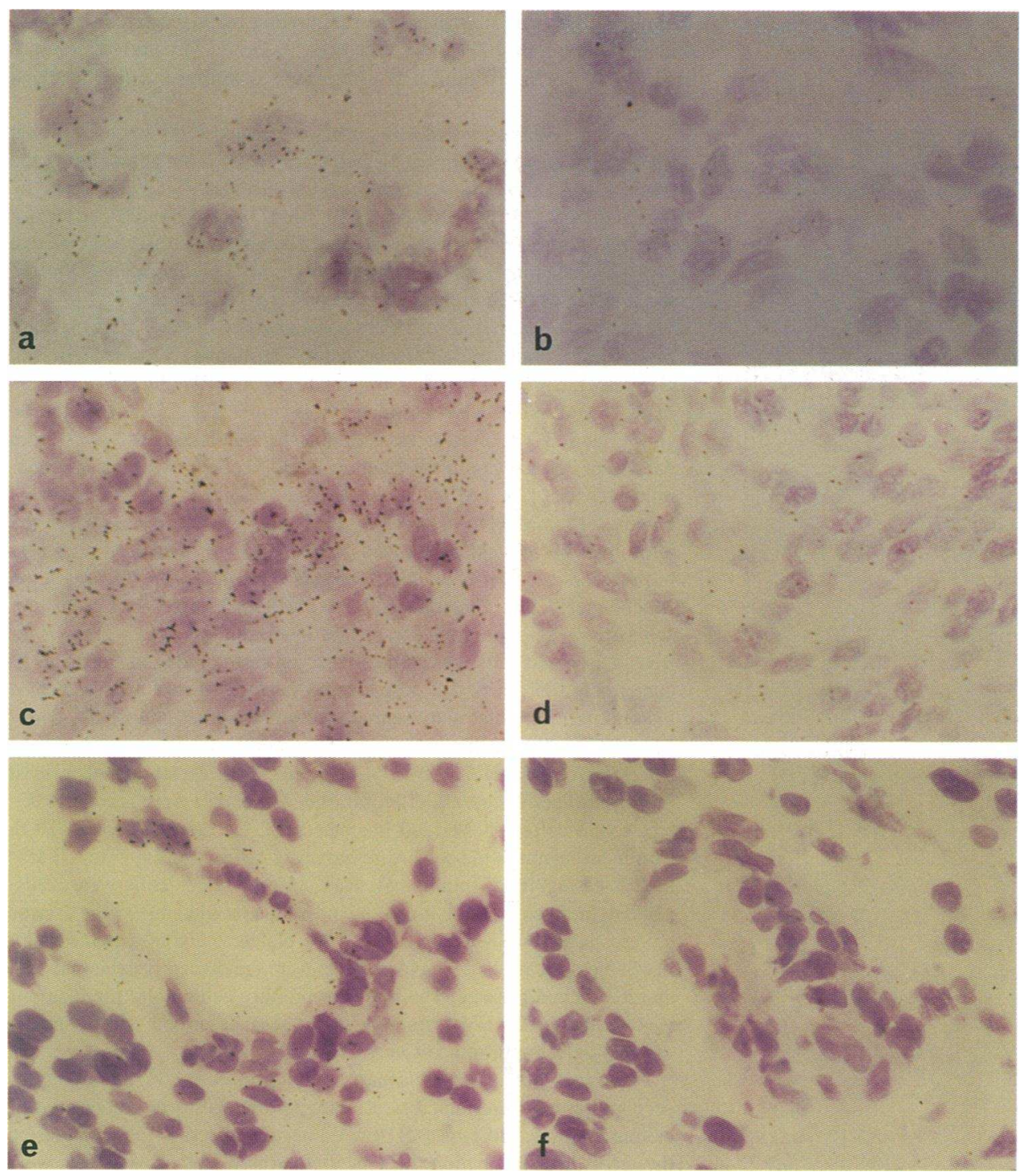

Figure 3. Expression of ET-1, ET$\mathrm{Ar}$, and ET-Br mRNAs in human meningiomas. ISH autoradiographs counterstained with cresylviolet. (a) Hybridization signals (silver grains) for ET-1 mRNA are seen over cells of a transitional meningioma. (c) ET-Ar mRNA is intensely expressed in a large number of cells of a meningotheliomatous meningioma. (e) Example of a meningotheliomatous meningioma blood vessel in whose side weak hybridization signals for ET-Br mRNA are detectable. $(b, d$, and $f)$ For negative control a 100 -fold excess of nonlabeled oligo was added to the radioactive probe and brought onto sections adjacent to $a, c$, and $e$ to confirm the specificity of the hybridization signals. Single silver grains on negative controls correspond to the background of the photoemulsion. $a-d$ $\times 800 ; e$ and $f \times 550$.

extraction (32, 33). $1 \mu \mathrm{g}$ RNA from meningiomas and human lung (Clontech, Palo Alto, CA) was subjected to reverse transcription as described previously (29). 40-cycle PCR for ET-1 and ET-receptors was performed, with each cycle consisting of denaturation at $94^{\circ} \mathrm{C}$ for 1 min, annealing of ET-1 primers at $60^{\circ} \mathrm{C}$, or of ET-receptor primers at $45^{\circ} \mathrm{C}$ for $1 \mathrm{~min}$ and chain extension at $72^{\circ} \mathrm{C}$ for $1 \mathrm{~min}$. Amplified PCR products were electrophoresed on a $1.8 \%$ agarose gel and stained with ethidium bromide. PCR primers (Table I) were selected from published ET-1 (34), ET-Ar (3), ET-Br (5) cDNA sequences as described previously $(29,35)$. All 5 '-primers covered splice junctions, thus excluding amplification of genomic DNA. RT-PCR for $\beta$-actin was performed as described (29). Specificity of amplification products was determined by Southern blotting, liquid hybridization with a digoxigenin (DIG)-labeled internal oligonucleotide probe (567-596 in exon III of pre-pro-ET-1 sequence), or DIG-labeled full-length human ET-Ar and ET-Br cDNAs (a generous gift from Dr. M. Yanagisawa, Howard Hughes Medical Institute, Southwestern Medical Center, Dallas, TX) and cheminoluminescent detection (DIG; Boehringer Mannheim, Mannheim, Germany).

ISH. ISH was performed according to the method of Wisden (36). In brief, $10-\mu \mathrm{m}$ sections of 24 meningiomas were fixed in $4 \%$ phosphatebuffered paraformaldehyde and stored in ethanol at $4^{\circ} \mathrm{C}$ until use. Two different deoxyoligonucleotides complementary to the mRNAs for human pre-pro-ET-1, ET-Ar, or ET-Br were synthesized (Table I). The two oligos for ET-Br recognized both splice variants (37). Deoxyoligo- nucleotides were $3^{\prime}$-end labeled with $\alpha-{ }^{35}$ S-dATP (Dupont, Bad Homburg, Germany) (molar ratio 1:30) by terminal transferase (Boehringer Mannheim). Unincorporated nucleotides were removed by Bio-Spin 6 columns (Bio-Rad, Munich, Germany) and $2 \mu \mathrm{l}$ of $1 \mathrm{M}$ DTT was added. After rehydration in PBS and a passage into $0.25 \%$ acetic anhydride in $0.1 \mathrm{M}$ triethanolamine- $\mathrm{HCl} \mathrm{pH} 8.0 / 0.9 \% \mathrm{NaCl}$ for $10 \mathrm{~min}$, sections were dehydrated in ethanol and finally air dried. Each section was hybridized for $16-20 \mathrm{~h}$ at $42^{\circ} \mathrm{C}$ with a solution containing $50,000-$ $200,000 \mathrm{cpm}$ of radioactive probe, $50 \%$ deionized formamide, $4 \times \mathrm{SSC}$, $10 \%$ dextran sulfate, $100 \mu \mathrm{g} / \mathrm{ml}$ polyadenylic acid, $5 \times$ Dehnardt's, 25 $\mathrm{mM}$ sodium phosphate, $\mathrm{pH} 7.0,1 \mathrm{mM}$ sodium pyrophosphate, and 200 $\mu \mathrm{g} / \mathrm{ml}$ salmon sperm DNA. After consecutive washes in $1 \times \mathrm{SSC}$ for $10 \mathrm{~min}$ at room temperature $(\mathrm{rt}), 1 \times \mathrm{SSC}$ for $30 \mathrm{~min}$ at $55^{\circ} \mathrm{C}, 1 \times \mathrm{SSC}$, $0.1 \times$ SSC for 1 min each at $r t$ and dehydration in ethanol, slides were dipped in Ilford K5 photoemulsion. After exposure of 6-8 wk, slides were developed in Kodak D-19 and fixed and counterstained with $0.5 \%$ cresylviolet. To control the specificity of the hybridization signal, a 100fold excess of nonlabeled oligonucleotides was added to the radioactive probe and applied to the adjacent section. The specificity of all six ISH oligonucleotide probes was controlled by Northern blot analysis on human lung mRNA.

IHC. Two antibodies (Ab) for ET-1 were used: a rabbit polyclonal (Peninsula, Heidelberg, Germany) and a mouse mAb (Dianova, Hamburg, Germany) (crossreactivity for ET-3: 7 and 2\%, respectively). From Dako (Hamburg, Germany) were mouse mAb for epithelial mem- 

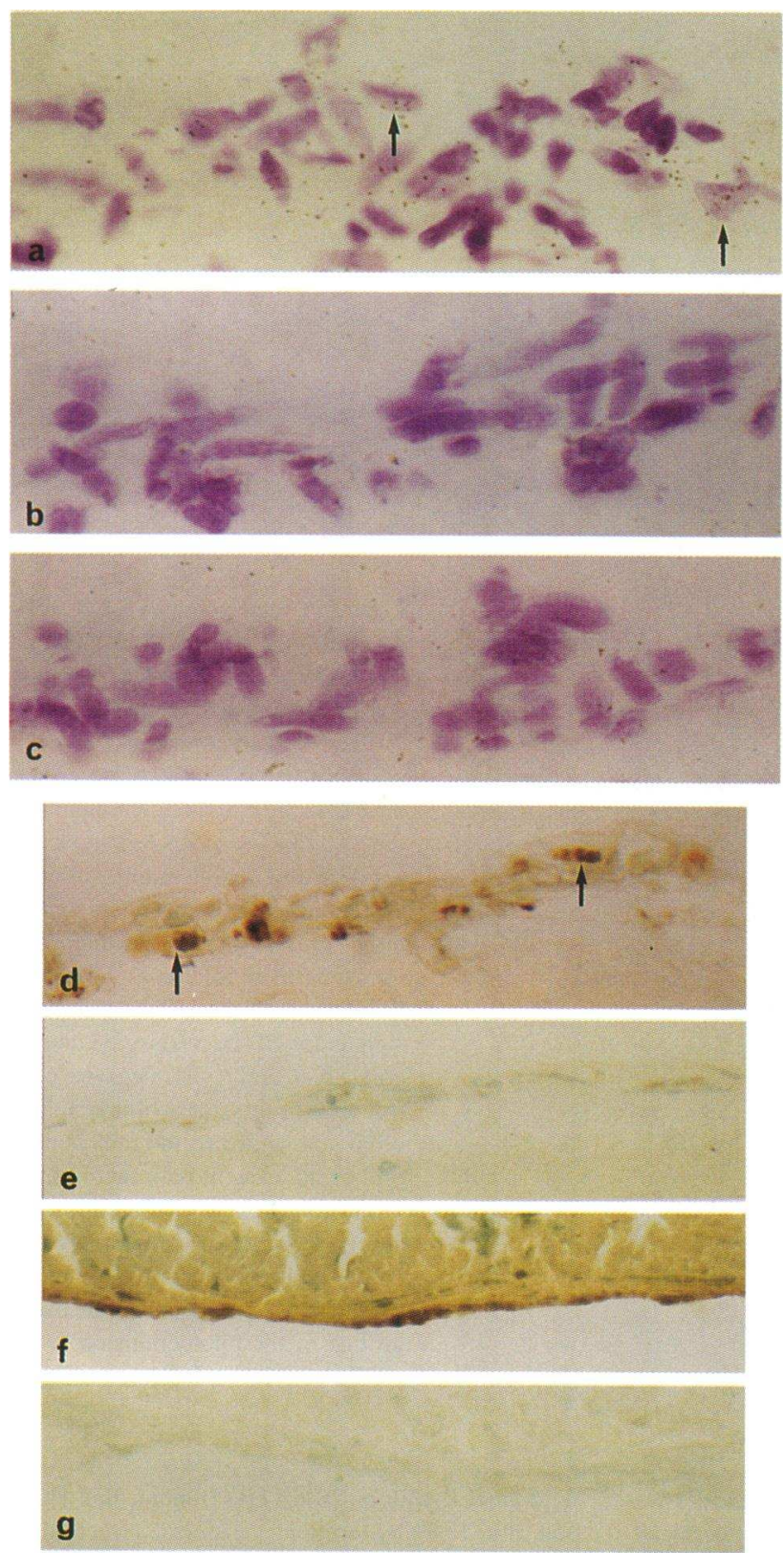

Figure 4. Expression of ET-1, ET-Ar, and ET-Br mRNAs, and ET-1 protein in normal human meninges. $(a-c)$ ISH autoradiographs counterstained with cresylviolet. $\times 800$. ( $a$ ) Only few cells show hybridization signals for ET-1 mRNA (black arrows), whereas no signals for ET-Ar $(b)$ and ET-Br $(c)$ mRNA are detectable in normal human leptomeninges. ( $d$ and $f$ ) IHC using a mAb for ET-1. ( $e$ and $g$ ) Negative controls. All sections are counterstained with cresylviolet. $\times 500$. $(d)$ Cells with ET-1-like immunoreactivity are scattered in human leptomeninges (black arrows $).(f)$ Flat cells lining the meningeal layer of human pachymeninges show ET-1-like immunoreactivity (dark brown staining). ( $e$ and $g$ ) Omitting the first antibody, no immunoreactivity is detectable in sections adjacent to $d$ and $f$.

brane antigen (EMA), a marker for meningioma tumoral cells (38), rabbit and swine serum, biotinylated swine anti-rabbit and rabbit antimouse IgGs. IHC was performed with minor modifications as described previously (29). In brief, after deparaffination and blockade of endogenous peroxidase with $0.25 \% \mathrm{KMnO}_{4}$, sections $(5 \mu \mathrm{m})$ were preincubated in rabbit or swine serum (1:10) followed by application of polyclonal or monoclonal ET-1 Ab (1:800-1:3,000 and 1:100-1:200) or EMA $\mathrm{Ab}(1: 50-1: 150)$ overnight at $4^{\circ} \mathrm{C}$. After incubation with the respective biotinylated IgGs ( $1: 300)$ and the streptavidin-biotin-horseradish peroxidase complex ( $1: 100)$ for $1 \mathrm{~h}$ at $\mathrm{rt}$ each, the enzymatic reaction was performed for $5-10 \mathrm{~min}$ at $\mathrm{rt}$ using $0.1 \%$ diaminobenzidine as chromogen.

Sections chosen for EMA staining were adjacent to sections in which ISH or IHC were performed. Negative controls were made omitting the primary antibody. The specificity of the ET-1 Ab was confirmed by preabsorption with synthetic ET-1 $\left(10^{-6} \mathrm{M}\right)$. For positive ET-1 controls, staining of large brain vessels was used. To exclude that the first negative or positive staining for ET-1 was derived from a particular field chosen, serial slides of the same pathological tissue have been tested.

Meningioma cell culture. Unless stated, materials and reagents were from Flow Laboratories (Meckenheim, Germany), Seromed (Berlin, Germany), Sigma (Munich, Germany), Gibco BRL (Eggenstein, Germany), and NUNC (Wiesbaden, Germany). ET-1, Sarafotoxin $6 c$ (S6c), and BQ-123 were from Peninsula and RES-701-3 was from American Peptide Company (Sunnyvale, CA). After washing in preparation buffer $\left(137 \mathrm{mM} \mathrm{NaCl}, 5 \mathrm{mM} \mathrm{KCl}, 0.7 \mathrm{mM} \mathrm{Na}_{2} \mathrm{HPO}_{4}, 10 \mathrm{mM}\right.$ glucose, $15 \mathrm{mM}$ Hepes, $\mathrm{pH} 7.3$, antibiotics), tissues were dissected into small pieces and both mechanically and enzymatically dispersed in preparation buffer containing $1,000 \mathrm{U} / \mathrm{ml}$ collagenase (Worthington Biochemical Corp., Freehold, NJ), $10 \mathrm{mg} /$ liter DNase II, $0.1 \mathrm{gram} /$ liter soybean trypsin inhibitor, 1 gram/liter hyaluronidase, and 4 grams/liter BSA. Dispersed cells were centrifuged and resuspended in sterile DME containing $10 \%$ FCS, 2.2 grams/liter $\mathrm{NaCO}_{3}, 10 \mathrm{mM}$ Hepes, $2 \mathrm{mM}$ glutamine, $10 \mathrm{ml} /$ liter nonessential medium vitamins, antibiotics, $5 \mathrm{mg}$ / liter insulin, $20 \mu \mathrm{g} /$ liter selenium, $5 \mathrm{mg} /$ liter transferrin, and $30 \mathrm{pM}$ triiodothyronine, $\mathrm{pH}$ 7.3. $2-3 \times 10^{6}$ cells, with a viability of at least $85 \%$ (acridine orange/ethidium bromide staining), were seeded in 75$\mathrm{cm}^{2}$ tissue culture flasks and incubated $\left(37^{\circ} \mathrm{C}, 5 \% \mathrm{CO}_{2}\right)$ for $8-10 \mathrm{~d}$. Confluent meningioma cells were harvested using trypsin ( $5 \mathrm{mg} / \mathrm{liter}$ )EDTA ( $2 \mathrm{mg} /$ liter) solution. At least $85 \%$ of viable cells were resuspended in fresh culture medium and either seeded in $75-\mathrm{cm}^{2}$ tissue culture flasks, in 48 -well tissue culture plates at 20,000 cells/well, or in double-slide flasks. All experiments were conducted between the first and the second passage. The purity of primary cell culture preparations was examined by EMA immunostaining as described above and by morphological appearance $(39,40)$.

Determination of $\left[{ }^{3} \mathrm{H}\right]$ thymidine incorporation. $\left[{ }^{3} \mathrm{H}\right]$ thymidine incorporation was determined as described previously with minor modifications (41). $0.5 \mu \mathrm{Ci} / \mathrm{ml}\left[{ }^{3} \mathrm{H}\right]$ thymidine was added to the cells during the last $3 \mathrm{~h}$ of incubation, then medium was removed, and cells were precipitated with ice-cold $10 \%$ trichloroacetic acid $\left(1 \mathrm{~h} ; 4^{\circ} \mathrm{C}\right)$ and washed with cold PBS. Then DNA was hydrolized overnight with 0.5 $\mathrm{M} \mathrm{NaOH} / 0.1 \%$ Triton X-100 and counted for radioactivity in a liquid scintillation counter.

IHC and autoradiography of $\left[{ }^{3} \mathrm{H}\right]$ thymidine-incorporating cell. Autoradiography was performed as described previously $(42,43)$. In brief, $1 \mu \mathrm{Ci} / \mathrm{ml}\left[{ }^{3} \mathrm{H}\right]$ thymidine was added to the cells during the last $3 \mathrm{~h}$ of incubation. After washing, cell monolayers were fixed in formaldehydeacetone and dried. IHC for EMA Ab was performed as described above with the exception of blocking endogenous peroxidase by $1 \% \mathrm{H}_{2} \mathrm{O}_{2}$. After the final enzymatic reaction, slides were dipped in Ilford $\mathrm{K} 5$ photoemulsion and exposed for $10 \mathrm{~d}$. Finally, slides were developed, fixed, and counterstained.

Bromodeoxyuridine staining. Bromodeoxyuridine (BrdU) staining was performed according to the instructions of the manufacturer (5bromo-2'-deoxy-uridine Labeling and Detection Kit I; Boehringer Mannheim). In brief, after a 45-min incubation of cells with $10 \mu \mathrm{M}$ BrdU, medium was removed and cells were fixed in $70 \%$ ethanol for $30 \mathrm{~min}$ at $-20^{\circ} \mathrm{C}$. Mouse $\mathrm{mAb}$ anti-BrdU (1:10) was applied and followed by anti-mouse-Ig-fluorescein (1:10).

Statistics. Statistics for growth studies on meningiomas were performed by ANOVA in combination with the Scheffe's test. Data are shown as mean \pm SD. In the in vitro studies, each experimental condition was performed in six replicates.

\section{Results}

Detection of ET-1, ET-Ar, and ET-Br mRNAs by RT-PCR. By RT-PCR, we found that in our series of 35 meningiomas $91 \%$ 

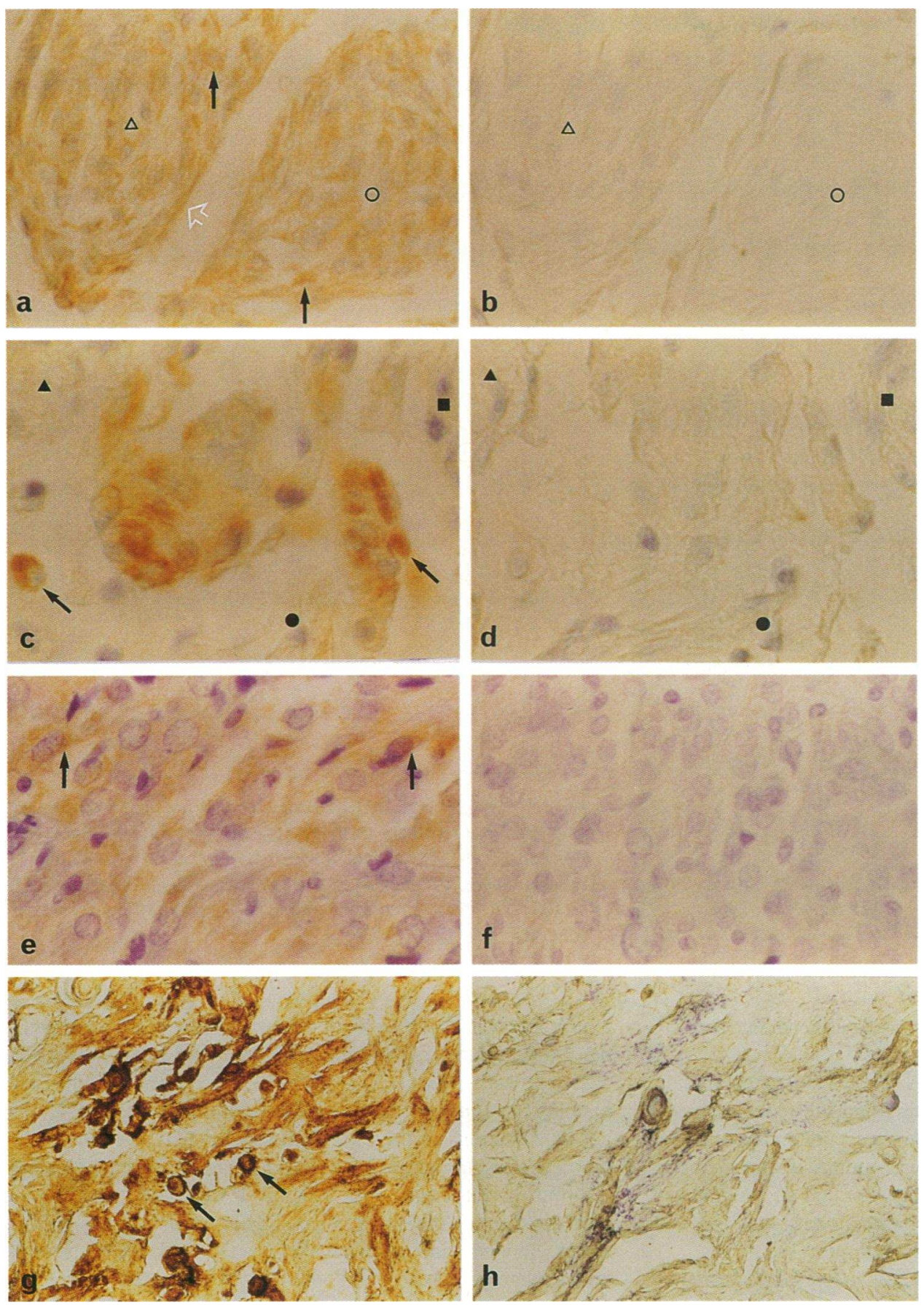

Figure 5. Expression of ET-1 protein in sections of different histological types of meningiomas. ( $a, c, e$, and g) Immunohistochemical localization using a mAb for ET-1. $(b, d, f$, and $h)$ Negative controls. All sections are counterstained with cresylviolet. An intense ET-1-like immunoreactivity (brown staining) is seen in cells (black arrows) of a transitional ( $a$ and $c$ ) and an atypical $(e)$ meningioma as well as in surrounding collagenous fibers ( $a$; white open arrow). $(g)$ Expression of ET-1 protein in a psammomatous meningioma. Note the strong immunoreactivity in the external part of psammoma body formations (black arrows), which are typical for this histological type. (b, $d, f$, and $h$ ) Omitting the first antibody, no immunoreactivity is detectable in sections adjacent to $a, c, e$, and $g$. Same symbols $(\square, O, \bullet, \Delta, \Delta)$ represent same areas. $a$ and $b \times 500$; $c-f \times 800 ; g$ and $h \times 100$.
(32 of 35) were positive for ET-1 mRNA, 82\% (29 of 35) for ET-Ar mRNA, and $42 \%$ ( 15 of 35 ) for ET-Br mRNA. The amplified 304-bp ET-1, 299-bp ET-Ar, and 428-bp ET-Br PCR cDNA fragments were of predicted molecular size, identical to cDNA fragments amplified from reversely transcribed mRNA of human lung (Fig. $1, A-C$ ). Tissues in which we were not able to detect ET-1, ET-Ar, or ET-Br mRNA were screened for $\beta$-actin mRNA expression using the same method. All tissues assayed in this way showed a positive signal for $\beta$-actin mRNA (data not shown) demonstrating that negative ET results by RT-PCR were not due to a degradation of mRNA.

The specificity of RT-PCR amplification products for ET1, ET-Ar, and ET-Br was confirmed by Southern blot (Fig. 2,
$A-C$ ) revealing the same pattern and intensity of bands and showing absence of crossreactivity.

Localization of ET-1, ET-Ar, and ET-Br mRNAs in meningiomas and normal meninges. The intracellular localization of ET-1, ET-Ar, and ET-Br mRNAs in tumors, which were positive for these mRNAs at RT-PCR, was additionally examined by ISH analysis.

A microscopic visualization of ISH for ET-1 mRNA revealed hybridization signals in most meningiomas examined in comparison with negative controls (Fig. 3, $a$ and $b$ ). The signals were not identical in all positive meningiomas, varying from low to medium-strong intensity; however, no correlation was found between signal intensity and histological type. In normal 

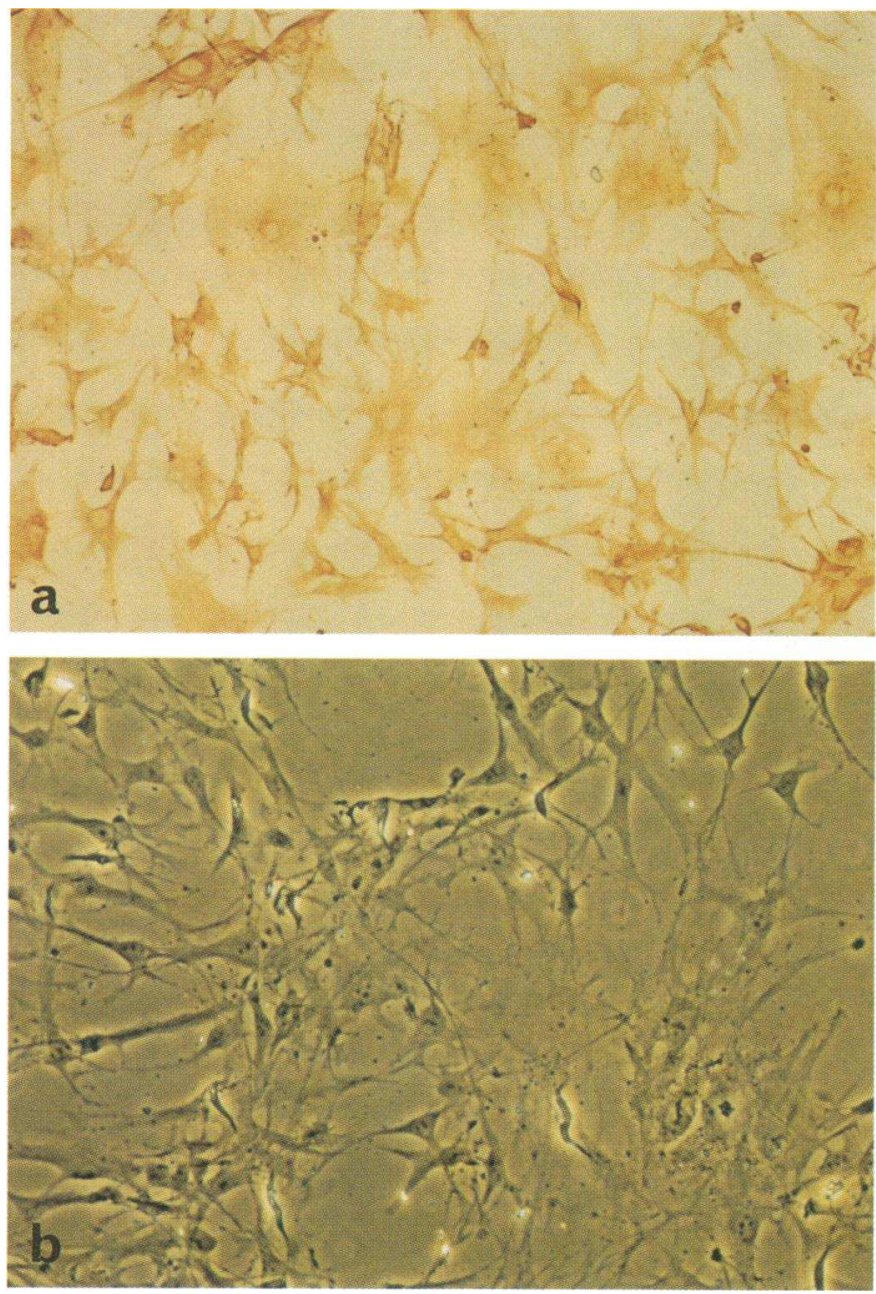

meninges only a few cells showed hybridization signals for ET1 mRNA (Fig. $4 a$ ).

In comparison with ET-1 mRNA, the hybridization signals for ET-Ar mRNA found in the meningiomas tested were more intense. At the microscopic level, a dense accumulation of silver grains, identifying ET-Ar mRNA, was seen over the majority of cells in all areas of the tumors (Fig. $3 c$ and $d$ ). In contrast to the strong hybridization signal in meningiomas, no signal for ET-Ar mRNA was found in normal meninges (Fig. $4 b$ ).

Oligonucleotides for ET-Br mRNA showed hybridization signals only in cells belonging to blood vessels (Fig. 3, $e$ and $f$ ). ET-Br mRNA was not detectable in normal meninges (Fig. $4 c$ ).

The two different oligonucleotides used for the detection of ET-1, ET-Ar, or ET-Br mRNAs showed the same topographical localization of hybridization signals for each mRNA on adjacent sections, confirming that the sequences chosen were specific. Another confirmation of specificity of all six oligonucleotides for ISH was obtained by Northern blot analysis on human lung mRNA (data not shown). Hybridization with both oligos for ET-Ar mRNA showed completely different signal patterns in comparison with those for ET-Br, proving that there was no mutual crosshybridization between them.

Expression of ET-1-like immunoreactivity in meningiomas and normal meninges. In 10 meningiomas, in which ET-1 mRNA was detected by RT-PCR and ISH, we also studied the expression of ET-1 at the protein level. By IHC, ET-1 protein
Figure 6. Morphological characterization and immunohistochemical identification of primary meningioma cells after $5 \mathrm{~d}$ in culture. $(a)$ Polygonal and elongated cells, which are typical for meningioma cells in culture, are stained (brown color) by using an mAb for EMA $(1: 100)$. (b) Phase-contrast. Omitting EMA antibody, no immunoreactivity is detectable. $\times 60$. expression was observed in all tissues examined. Similar results were obtained with both antibodies described in Methods. Fig. $5, a, c, e$, and $g$ show ET-1-like immunoreactivity in different histological types of meningiomas. Omitting the first $\mathrm{Ab}$ in adjacent sections of the same tumor (Fig. $5, b, d, f$, and $h$ ) or preincubating the antisera with an excess of ET-1 peptide, no staining for ET-1 was observed. ET-1 was found not only in cells constituting the tumor, but could also be detected in collagenous elements and occasionally in some cells lining vessels which were presumably endothelial cells. Psammoma bodies, which are frequently seen in transitional and dominating in psammomatous meningiomas, were also stained for ET-1 (Fig. $5 \mathrm{~g}$ ). There was no apparent correlation between the different histological types and the intensity of ET-1 staining. Normal human leptomeninges showed only a scattered distribution of cells positive for ET-1-like immunoreactivity (Fig. $4 d$ ). Only the meningeal layer of normal human pachymeninges exhibited diffuse immunostaining for ET-1 (Fig. $4 f$ ). No staining for ET-1 was observed in adjacent sections in absence of the first antibody (Fig. 4, $e$ and $g$ ). Positive staining in large vessels of the brain confirmed the specificity of the ET-1 Abs (data not shown).

Immunoreactivity for EMA in meningiomas. All meningiomas showed an intense immunoreactivity for EMA (data not shown). Groups of cells, positive for ET-1 mRNA, ET-Ar mRNA, or ET-1-like immunoreactivity, were identified as being positive for EMA staining in adjacent sections. 


$$
\square \mathrm{ET}-1 \quad \square \mathrm{ET}-1+\mathrm{BQ}-123
$$

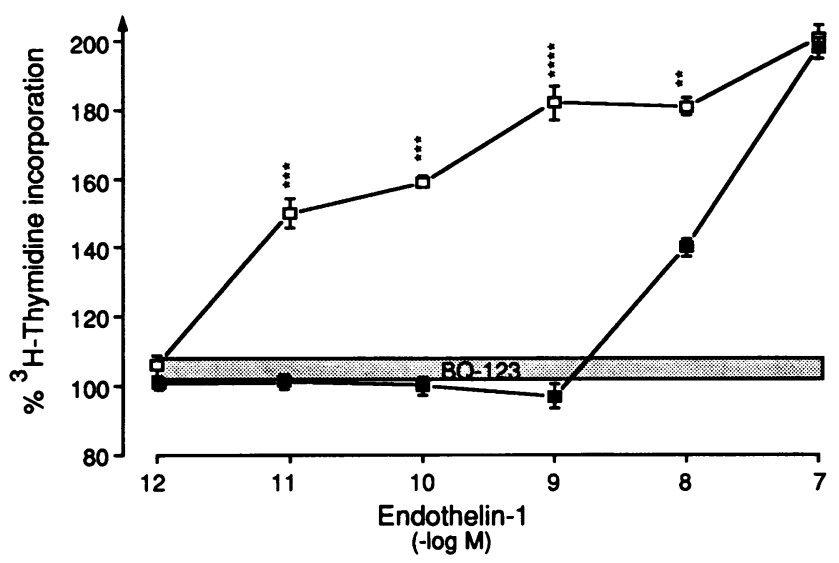

Figure 7. Stimulatory effect on anaplastic meningioma DNA synthesis of ET-1, and its reversal by BQ-123, an antagonist of type-A receptor. Meningioma cells were cultured at the second passage $\left(2 \times 10^{4}\right.$ viable cells $/ 0.5 \mathrm{ml}$ ) in DME with all ingredients and 10\% FCS for $4 \mathrm{~d}$, then washed and cultured for $24 \mathrm{~h}$ in DME only supplemented with antibiotics, glutamine, selenium, and transferrin to induce quiescence. After replacing with fresh medium containing antibiotics, glutamine, selenium, and transferrin, cells were treated in absence of FCS for $48 \mathrm{~h}$ with ET-1 ( $\square$ ) or with BQ-123 $\left(10^{-6} \mathrm{M}\right)$ (bar) or with BQ-123 $\left(10^{-6}\right.$ $\mathrm{M})$ in combination with ET-1 (a). $\left[{ }^{3} \mathrm{H}\right]$ thymidine incorporation (3-h pulse) was determined as described in Methods. Results represent the percentage $\pm \mathrm{SD}(n=6)$ of one representative meningioma. The mean basal control value $\pm \mathrm{SD}$ for $\left[{ }^{3} \mathrm{H}\right]$ thymidine incorporation was:

$3,559 \pm 177 \mathrm{cpm}$. $* * * * P<0.0001, * * * P<0.001, * * P<0.01$.

ET-1 effect on DNA synthesis on human meningioma cells in culture. The purity of our primary cultures was verified by EMA staining (Fig. 6). In all 20 cultivated meningiomas we found that increasing concentrations $\left(10^{-12}\right.$ to $\left.10^{-7} \mathrm{M}\right)$ of ET1 induced a marked elevation of thymidine incorporation in a dose-dependent manner in the absence of FCS. The stimulation of $\left[{ }^{3} \mathrm{H}\right]$ thymidine incorporation in meningioma cells in the presence of $10^{-7} \mathrm{M}$ ET-1 ranged from 180 to $300 \%$ above the basal level (a representative experiment is shown in Fig. 7). This was $25 \%$ of that induced by $10 \%$ FCS (data not shown). ET1 stimulatory activity was similar in all histological types of meningiomas examined. Autoradiography combined with IHC staining for EMA in cell culture confirmed that the cells incorporating thymidine were tumoral cells (Fig. $8 a$ ). Moreover, BrdU fluorescence staining clearly demonstrated that the incorporation was nuclear (Fig. $8 \mathrm{~b}$ ). To prove which of the two ET receptor types mediates the ET-1-stimulated proliferation, growth studies were performed in the presence of selective ETAr and ET-Br antagonists. BQ-123, a specific ET-Ar antagonist, was demonstrated to be effective at concentrations of $10^{-6} \mathrm{M}$ (a representative experiment is shown in Fig. 7). In contrast, RES-701-3, a specific ET-Br antagonist, used at the same concentration was completely unable to antagonize the ET-1 effect (data not shown). Moreover, S6c, an ET agonist acting specifically via ET-Br, did not affect meningioma proliferation at concentrations of $10^{-6} \mathrm{M}$ (data not shown).

\section{Discussion}

We demonstrate for the first time the expression of ET-1 as well as the topographical localization of ET receptor mRNA in human meningiomas. Moreover we show that ET-1, acting via ET-Ar, is a mitogen in meningioma cells in vitro, suggesting an important role of this peptide in the development and maintenance of meningioma tumors in vivo.

Meningiomas are frequent neoplasias of the brain, accounting for $13.4-27.3 \%$ of all primary intracranial tumors (44). While arachnoid cells are thought to be the major components of meningiomas, other cellular components of pia, arachnoid, or dura such as fibroblasts or endothelial cells may take part in the tumor formation in varying proportion (38). ET-1 has been shown to stimulate protooncogene expression and growth of fibroblasts, cultured endothelial, and vascular smooth muscle cells (for review see reference 12). Here we demonstrate that ET-1 promotes DNA synthesis in cultures of purified meningioma cells of different histological classification. Since the proliferation of meningioma cells induced by ET-1 is reversed by the specific ET-Ar antagonist BQ-123, but affected by neither the ET-Br antagonist RES-701-3 (45) nor the ET-Br agonist S6c, we can conclude that the mitogenic action of ET-1 is mediated by type A receptor. These in vitro data are consistent with intense in vivo hybridization signals for ET-Ar, for which ET-1 is the most important physiological ligand. In contrast, low hybridization signals for ET-Br mRNA were localized only in cells belonging to blood vessels. The findings that the intense hybridization signals for ET-Ar mRNA correspond to a strong immunoreactivity for the meningioma cell marker EMA in the same groups of cells in adjacent sections, as well as the observation that the majority of cells in each slide contained silver grains for ET-Ar, strongly suggest that mRNA for this receptor is expressed in tumoral cells. In contrast to the abundant ETAr mRNA expression in our series of meningiomas, we did not find any signal for ET-Ar mRNA in normal meninges. We found no correlation between ET-Ar mRNA expression and different histological types of the meningiomas. Thus, we hypothesize that the aberrant ET-Ar mRNA expression in meningiomas plays a role in a very early stage of the tumoral transformation and progression.

An abnormal expression of different growth factors and/or their receptors has been found in meningiomas $(23,24,27,46)$. Many of these peptides, including cytokines (47), have been demonstrated to be produced by meningiomas acting as selfmaintaining intratumoral promoters. The mitogenic activity of ET-1, together with abundant ET-Ar mRNA expression in meningiomas, allows us to include ET-1 in the family of these growth factors which may contribute to the development of these tumors.

In the brain, ET-1 expression has been demonstrated in endothelial cells of medium- and large-diameter cerebral and arachnoidal blood vessels (7). Since ET-1 is found in vascular endothelium, this peptide is thought to participate in the angiogenesis occurring during the establishment of the neoplasia in vivo in concert with other angiogenic agents (48). Thus, ET1 might be involved in the tumorigenesis of well vascularized brain tumors, such as gliomas $(28,49)$ and pituitary adenomas (29). It was not surprising to us to detect ET-1 mRNA and protein in blood vessels of meningiomas, which are also well vascularized brain neoplasias. In addition, we have shown that ET-1 mRNA and protein are also present in neoplastic cells which constitute the predominant cell type of the tumor. Therefore, we could conclude that in vivo ET-1 may influence the growth of the whole mass of the tumor constituted by various cell types.

Recently it has been shown in mice that ET-1 gene disrup- 

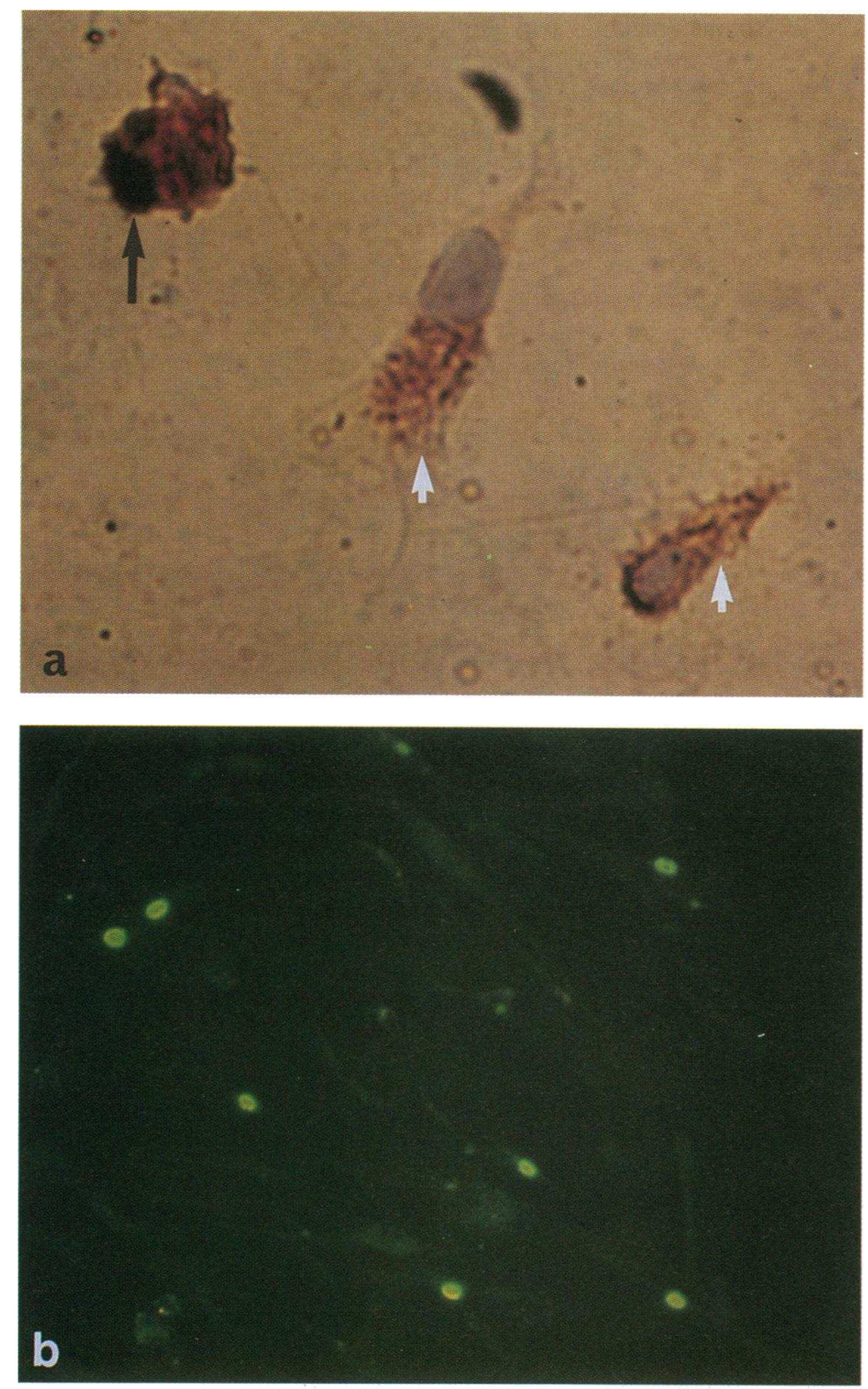

Figure 8. Identification and characterization of cells of different types of meningiomas in culture undergoing DNA synthesis after ET-1 stimulation. Meningioma cells were cultured at the second passage in DME with all ingredients and $10 \%$ FCS for $4 \mathrm{~d}$, then washed and cultured for $24 \mathrm{~h}$ in DME only supplemented with antibiotics, glutamine, selenium, and transferrin. Then cells were stimulated with ET-1 $\left(10^{-7} \mathrm{M}\right)$ in fresh DME supplemented as above for $48 \mathrm{~h} .(a)\left[{ }^{3} \mathrm{H}\right]-$ thymidine was added for $3 \mathrm{~h} ;(b)$ cells were pulsed for 45 min with BrdU. Autoradiography, immunohistochemistry, and immunofluorescence were performed as described in Methods. (a) $\left[{ }^{3} \mathrm{H}\right]$ thymidine incorporation (black arrow) is seen in the nucleus of an EMA-positive cell cultivated from a meningotheliomatous meningioma. Other EMA-positive cells (brown staining; white arrows) do not incorporate $\left[{ }^{3} \mathrm{H}\right]$ thymidine. Counterstaining with cresylviolet. $\times 1,000$. (b) BrdU is incorporated in the nuclei of many cells cultivated from a fibroblastic meningioma. $\times 250$ tion causes severe craniofacial deformities in the organs developed from the pharyngeal arches, whose origin is mainly from neural crest-derived ectomesenchymal cells (50). ET-1 is also involved in the human fetal development of neural crest-derived craniofacial tissues $(51)$. Since the neural crest gives rise to the pia mater and arachnoid $(52,53)$, an autocrine/paracrine action of ET-1 via type A receptor seems to be important in fetal development. ET-1 may alsoplay a role in the development of tumors deriving from the same embryological origin similar to what has already been described for other growth factors $(30)$

The abnormal expression of various growth factors and/or their receptors has been shown to be involved in the pathogenesis of tumors. Our data prompt us to hypothesize that ET-1 also plays a role in the mechanism of meningioma tumorigenesis. Still taking into account the potential role of other growth factors, we can speculate that ET-A receptors may provide a potential target for a therapy in meningiomas which are nonresectable or progress after initial surgical treatment.

\section{Acknowledgments}

We wish to thank Rosa Buric, Johanna Stalla, Roswitha Schneider, and Silja Tauriainen for their excellent technical assistance; and Sigrid Madsen from the Institute of Pathology of the University of Munich for her technical help in the autoradiographic procedure. We thank Dr. Masashi Yanagisawa, Howard Hughes Medical Institute and Department of Molecular Genetics, University of Texas, Southwestern Medical Center at Dallas for human ET-Ar and human ET-Br cDNAs. We are also grateful to Dr. Tullio Barni, Institute of Human Anatomy, University of Florence, Italy for his helpful suggestions concerning our manuscript.

\section{References}

1. Yanagisawa, M., H. Kurihara, S. Kimura, Y. Tomobe, M. Kobayashi, Y. Mitsui, Y. Yazaki, K. Goto, and T. Masaki. 1988. A novel potent vasoconstrictor peptide produced by vascular endothelial cells. Nature (Lond.) 332:411-415.

2. Inoue, A., M. Yanagisawa, S. Kimura, Y. Kasuya, T. Miyauchi, K. Goto, and T. Masaki. 1989. The human endothelin family: three structurally and pharmacologically distinct isopeptides predicted by three separate genes. Proc. Natl. Acad. Sci. USA. 86:2863-2867. 
3. Hosoda, K., K. Nakao, H. Arai, S. Suga, Y. Ogawa, M. Mukoyama, G. Shirakami, Y. Saito, S. Nakanishi, and H. Imura. 1991. Cloning and expression of human endothelin-1 receptor cDNA. FEBS Lett. 287:23-26.

4. Ihara, M., K. Noguchi, T. Saeki, T. Fukuroda, S. Tsuchida, S. Kimura, T. Fukami, K. Ishikawa, M. Nishikibe, and M. Yano. 1992. Biological profiles of highly potent novel endothelin antagonists selective for the $\mathrm{ET}_{\mathrm{A}}$ receptor. Life Sci. 50:247-255.

5. Ogawa, Y., K. Nakao, H. Arai, O. Nakagawa, K. Hosoda, S. Suga, S. Nakanishi, and H. Imura. 1991. Molecular cloning of a non-isopeptide-selective human endothelin receptor. Biochem. Biophys. Res. Commun. 178:248-255.

6. Rubanyi, G. M., and M. A. Polokoff. 1994. Endothelins: molecular biology, biochemistry, pharmacology, physiology, and pathophysiology. Pharmacol. Rev. 46:325-415.

7. Lee, M.-E., S. M. de la Monte, S.-C. Ng, K. D. Bloch, and T. Quertermous. 1990. Expression of the potent vasoconstrictor endothelin in the human central nervous system. J. Clin. Invest. 86:141-147.

8. McCumber, M. W., C. A. Ross, B. M. Glaser, and S. H. Snyder. 1989. Endohelin: visualization of mRNAs by in situ hybridization provides evidence for local action. Proc. Natl. Acad. Sci. USA. 86:7285-7289.

9. McCumber, M. W., C. A. Ross, and S. H. Snyder. 1990. Endothelin in brain: receptors, mitogenesis, and biosynthesis in glial cells. Proc. Natl. Acad. Sci. USA. 87:2359-2363.

10. Ehrenreich, H., J. H. Kehrl, R. W. Anderson, P. Rieckmann, L. Vitkovic, J. E. Coligan, and A. S. Fauci. 1991. A vasoactive peptide, endothelin-3, is produced by and specifically binds to primary astrocytes. Brain Res. 538:54-58.

11. Gulati, A., and R. C. Srimal. 1992. Endothelin mechanisms in the central nervous system: a target for drug development. Drug Dev. Res. 26:361-387.

12. Battistini, B., P. Chailler, P. D'Orleans-Juste, N. Briere, and P. Sirois. 1993. Growth regulatory properties of endothelins. Peptides. 14:385-399.

13. Pribnow, D., L. L. Muldoon, M. Fajardo, L. Theodor, S. L. Y. Chen, and B. E. Magun. 1992. Endothelin induces transcription of fos/jun family genes: a prominent role for calcium ion. Mol. Endocrinol. 6:1003-1012.

14. Vigne, P., R. Marsault, J. P. Breittmayer, and C. Frelin. 1990. Endothelin stimulates phosphatidylinositol hydrolysis and DNA synthesis in brain capillary endothelial cells. Biochem. J. 266:415-420.

15. Komuro, I., H. Kurihara, T. Sugiyama, F. Takaku, and Y. Yazaki. 1988. Endothelin stimulates c-fos and c-myc expression and proliferation of vascular smooth muscle cells. FEBS Lett. 238:249-252.

16. Shichiri, M., Y. Hirata, T. Nakajima, K. Ando, T. Imai, M. Yanagisawa, T. Masaki, and F. Marumo. 1991. Endothelin-1 is an autocrine/paracrine growth factor for human cancer cell lines. J. Clin. Invest. 87:1867-1871.

17. Kusuhara, M., K. Yamaguchi, K. Nagasaki, C. Hayashi, A. Suzaki, S. Hori, S. Handa, Y. Nakamura, and K. Abe. 1990. Production of endothelin in human cancer cell lines. Cancer Res. 50:3257-3261.

18. Giaid, A., Q. A. Hamid, D. R. Springall, M. Yanagisawa, O. Shinmi, T. Sawamura, T. Masaki, S. Kimura, B. Corrin, and J. M. Polak. 1990. Detection of endothelin immunoreactivity and mRNA in pulmonary tumours. J. Pathol. 162:15-22.

19. Ishibashi, M., M. Fujita, K. Nagai, M. Kako, H. Furue, E. Haku, Y. Osamura, and T. Yamaji. 1993. Production and secretion of endothelin by hepatocellular carcinoma. J. Clin. Endocrinol. Metab. 76:378-383.

20. Takahashi, K., F. Satoh, O. Murakami, K. Totsune, M. Sone, K. Itoi, M Ohneda, and T. Mouri. 1993. Endothelin in ectopic ACTH-secreting bronchial carcinoid tumors. J. Cardiovasc. Pharmacol. 22(Suppl. 8):S288-S290.

21. Sporn, M. B., and A. B. Roberts. 1985. Autocrine growth factors and cancer. Science (Wash. DC). 313:745-747.

22. Ekstrand, A. J., C. D. James, W. K. Cavenee, B. Seliger, R. F. Pettersson, and V. P. Collins. 1991. Genes for epidermal growth factor receptor, transforming growth factor $\alpha$, and epidermal growth factor and their expression in human gliomas in vitro. Cancer Res. 51:2164-2172.

23. Weisman, A. S., S. S. Raguet, and P. A. Kelly. 1987. Characterization of the epidermal growth factor receptor in human meningioma. Cancer Res. 47:2172-2176.

24. Antoniades, H. N., T. Galanopoulos, J. Neville-Golden, and M. Maxwell. 1992. Expression of insulin-like growth factors I and II and their receptor mRNAs in primary human astrocytomas and meningiomas; in vivo studies using in situ hybridization and immunocytochemistry. Int. J. Cancer. 50:215-222.

25. Takahashi, J. A., H. Mori, M. Fukumoto, K. Igarashi, M. Jaye, Y. Oda, H. Kikuchi, and M. Hatanaka. 1990. Gene expression of fibroblast growth factors in human gliomas and meningiomas: demonstration of cellular source of basic fibroblast growth factor mRNA and peptide in tumor tissues. Proc. Natl. Acad. Sci. USA. 87:5710-5714.

26. Maxwell, M., S. P. Naber, H. J. Wolfe, E. T. Hedley-Whyte, T. Galanopoulos, J. Neville-Golden, and H. N. Antoniades. 1991. Expression of angiogenic growth factors genes in primary human astrocytomas may contribute to their growth and progression. Cancer Res. 51:1345-1351.

27. Maxwell, M., S. P. Naber, H. J. Wolfe, T. Galanopoulos, T. E. HedleyWhyte, P. M. Black, and H. N. Antoniades. 1990. Coexpression of platelet-derived growth factor (PDGF) and PDGF-receptor genes by primary human astrocytomas may contribute to their development and maintenance. J. Clin. Invest. 85:131140
28. Kurihara, M., A. Ochi, T. Kawaguchi, M. Niwa, Y. Kataoka, and K. Mori. 1990. Localization and characterization of endothelin receptors in human gliomas: a growth factor? Neurosurg. 27:275-281.

29. Lange, M., U. Pagotto, U. Hopfner, H. Ehrenreich, R. Oeckler, F. Sinowatz, and G. K. Stalla. 1994. Endothelin expression in normal human anterio pituitaries and pituitary adenomas. J. Clin. Endocrinol. Metab. 79:1864-1870.

30. Cross, M., and T. M. Dexter. 1991. Growth factors in development, transformation and tumorigenesis. Cell. 64:271-280.

31. Zülch, K. G. 1979. Histological typing of tumors of the central nervous system. In International Histologic Classification of Tumors, No. 21. World Health Organization. Geneva. 47-60.

32. Chomczynski, P., and N. Sacchi. 1987. Single-step method of RNA isolation by acid guanidinium thiocyanate-phenol-chloroform extraction. Anal. Biochem. 162:156-159.

33. Stalla, G. K., J. Stalla, M. Huber, J.-P. Loeffler, V. Höllt, K. von Werder, and O. A. Müller. 1988. Ketoconazole inhibits corticotropic cell function in vitro. Endocrinology. 122:618-623.

34. Bloch, K. D., S. P. Friedrich, M.-E. Lee, R. L. Eddy, T. B. Shows, and T. Quertermous. 1989. Structural organization and chromosomal assignment of the gene encoding endothelin. J. Biol. Chem. 264:10851-10857.

35. Davenport, A. P., G. O'Reilly, P. Molenaar, J. J. Maguire, R. E. Kuc, A Sharkey, C. R. Bacon, and A. Ferro. 1993. Human endothelin receptors characterized using reverse transcriptase-polymerase chain reaction, in situ hybridization and subtype-selective ligands BQ123 and BQ3020: evidence for expression of ETB receptors in human vascular smooth muscle. J. Cardiovasc. Pharmacol. 22(Suppl. 8):S22-S25.

36. Wisden, W., B. J. Morris, and S. P. Hunt. 1991. In situ hybridization with synthetic DNA probes. In Molecular Neurobiology. A Practical Approach. Vol II. J. Chad and W. H. Wheal, editors. IRL Press/Oxford University Press, Oxford. 205-225.

37. Shyamala, V., T. H. M. Moulthrop, J. Stratton-Thomas, and P. TekampOlson. 1994. Two distinct human endothelin B receptors generated by alternative splicing from a single gene. Cell. Mol. Biol. Res. 40:285-296.

38. Chou, S. M., and J. M. Miles. 1991. The pathology of meningiomas. In Meningiomas. O. Al-Mefty, editor. Raven Press, New York. 37-57.

39. Zava, D. T., T. M. Markwalder, and R. V. Markwalder. 1984. Biological expression of steroid hormone receptors in primary meningioma cells in monolayer culture. Clin. Neuropharmacol. 7:382-388.

40. Maiuri, F., S. Montagnani, B. Gallicchio, M. Caradente, G. G. Lanza, and F. D'Andrea. 1989. Oestrogen and progesterone sensitivity in cultured meningioma cells. Neurol. Res. 11:9-13.

41. Renner, U., J. Mojto, E. Arzt, M. Lange, J. Stalla, O. A. Müller, and G. K. Stalla. 1993. Secretion of polypeptide growth factors by human nonfunctioning pituitary adenoma cells in culture. Neuroendocrinology. 57:825-834.

42. Tilemans, D., M. Andries, and C. Denef. 1991. Luteinizing hormonereleasing hormone and neuropeptide $\mathrm{Y}$ influence desoxyribonucleic acid replication in three anterior pituitary cell types. Evidence for mediation by growth factors released from gonadotrophs. Endocrinology. 130:882-894.

43. Arzt, E., J. Sauer, R. Buric, J. Stalla, U. Renner, and G. K. Stalla. 1995. Characterization of Interleukin-2 (IL-2) receptor expression and action of IL-2 and IL-6 on normal anterior pituitary cell growth. Endocrine. 3:113-119.

44. Rachlin, J. R., and M. L. Rosenblum. 1991. Etiology and biology of meningiomas. In Meningiomas. O. Al-Mefty, editor. Raven Press, New York 27-35.

45. Tanaka, T., E. Tsukuda, M. Nozawa, H. Nonaka, T. Ohno, H. Kase, K Yamada, and Y. Matsuda. 1994. RES-701-1, a novel, potent, endothelin type B receptor selective antagonist of microbial origin. Mol. Pharmacol. 45:724-730.

46. Johnson, M. D., C. F. Federspiel, L. I. Gold, and H. L. Moses. 1992. Transforming growth factor $\alpha$ and transforming growth factor receptor $\beta$ expression in human meningioma cells. Am. J. Pathol. 141:633-642.

47. Todo, T., E. F. Adams, B. Rafferty, R. Fahlbusch, T. Dingermann, and H. Werner. 1994. Secretion of interleukin- 6 by human meningioma cells: possible autocrine inhibitory regulatory of neoplastic cell growth. J. Neurosurg. 81:394-401.

48. Economos, K., P. C. MacDonald, and M. L. Casey. 1992. Endothelin-1 gene expression and biosynthesis in human endometrial HEC-1A cancer cells Cancer Res. 52:554-557.

49. Ladenheim, R. G., I. Lacroix, N. Foignant-Chaverot, A. D. Strosberg, and P. O. Couraud. 1993. Endothelins stimulate c-fos and nerve growth factor expression in astrocytes and astrocytoma. J. Neurochem. 60:260-266.

50. Kurihara, Y., H. Kurihara, H. Suzuki, T. Kodama, K. Maemura, R. Nagai, H. Oda, T. Kuwaki, W. Cao, N. Kamada, et al. 1994. Elevated blood pressure and craniofacial abnormalities in mice deficient in endothelin-1. Nature (Lond.). 368:703-710.

51. Barni, T., M. Maggi, G. Fantoni, M. Serio, I. Tollaro, L. Gloria, and G. B. Vannelli. 1994. Evidences of endothelin involvement in the development of pharingeal-arch-derived craniofacial tissue. In Endothelins in Endocrinology: New Advances. Ares Serono, Florence. 27.

52. Jacobson, M. 1993. Developmental Neurobiology. Plenum Press, New York, London. 148.

53. Larsen, W. J. 1993. Human Embriology. Churchill Livingstone, New York, Edinburgh, London, Melbourne, Tokyo. 78-79. 